\section{European \\ Surgical Research}

Eur Surg Res 2003;35:455-456

DOI: $10.1159 / 000073382$

\title{
Prof. Dr. Roger Bénichoux 1919-2003
}

On June 20th 2003 Professor Emeritus Roger Bénichoux passed away in his home in La Grande Motte, France.

With him the European Society for Surgical Research has lost its founder and later Honorary President, a man with special charisma, empathy and vision for a scientific and political European Union.

Roger Bénichoux was born in Tiemcen, Algeria, on December 25th 1919. In 1938 he began to study medicine at the University of Montpellier, France, was an auxiliary doctor of the colonial troops in Mostaganem, Algeria in 1943, and later participated in the Second World War in Corsica and Alsace. He was first decorated in 1944 and later in 1965 with the military title Chevalier de l'ordre national du Mérite. He started his internship in 1946 at the Hôpital Marin in Nancy. From 1949 to 1950 he worked as a foreign fellow with Professor Clarence Crawford at the Karolinska Institute in Stockholm, Sweden. This experience was decisive for his further career as surgeon and scientist. In January 1951 he presented his Thesis to the medical faculty in Nancy.

In 1955, he became professeur agrégé de chirurgie générale, in 1957 staff surgeon and in 1960 he started to work with Professor Chalnot in cardiothoracic surgery in the Service Chirurgie A of the Hospital Central, Nancy. In the same year, he created the Clinic Ambroise-Paré (62 beds) and was appointed Chef de Service de Chirurgie A of the Hospital Central of Nancy and Hospital Brabois in Nancy-Vandœuvre.

In 1969, he established the Surgical Research Institute of the medical faculty in Brabois, of which he remained director until his retirement from the hospital and the university in 1968.

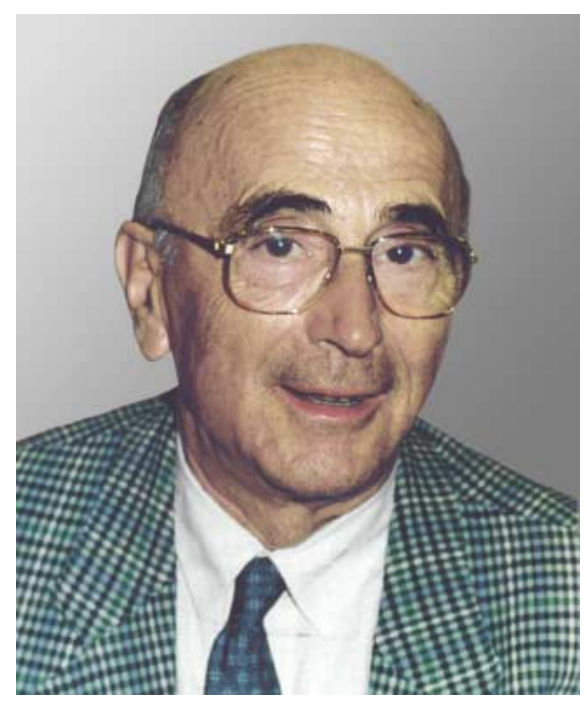

Roger Bénichoux is merited in the medical faculty of the University of Nancy for having performed the first open heart operation in Nancy in 1958, the installation of a chamber for hyperbaric oxygenation and the foundation of the Institute for Surgical Research.

His fields of interest were very broad and ranged from breast cancer, pulmonary embolism, newborn surgery, burns, cardiac and vascular surgery up to biomaterials, with more than 300 publications in the time between 1946 and 1997.

Among these publications are several books, three of them dealing with one of his favorite nonsurgical topics namely 'Guide to medical and scientific publication'; in addition, in 1978 he founded COFECOS (Collège Français d'Enseignement de la Communication Scientifique, last congress in 1993 in Montpellier/France).

\begin{tabular}{ll}
\hline KARGER & $\begin{array}{l}\text { ( ) 2003 S. Karger AG, Basel } \\
0014-312 X / 03 / 0356-0455 \$ 19.50 / 0\end{array}$ \\
$\begin{array}{l}\text { Fax +4161306 12 34 } \\
\begin{array}{l}\text { E-Mail karger@karger.ch } \\
\text { www.karger.com }\end{array}\end{array}$ & $\begin{array}{l}\text { Accessible online at: } \\
\text { www.karger.com/esr }\end{array}$
\end{tabular}


Of particular interest to me is the monograph 'Quand les chirurgiens étaient rois: vie de Clarence Crawford' (Presses Universitaires de Nancy, 1991), an homage to his great teacher and tutor in Stockholm, for whom Roger Bénichoux preserved great respect and admiration throughout his whole life.

The maxime for his life he found in De Trinitate, 13th book from Aurelius Augustinus de Hipo (Africa): 'Pouvoir ce que l'on veut, vouloir ce qu'il faut.'

In accordance, with this maxime, he had the desire to establish experimental surgery as an academic discipline and to create a scientific organization to assemble those in Europe working in experimental surgical research.

It was therefore no surprise that he invited experimental and clinical surgeons to attend the first meeting in France devoted exclusively to experimental surgery, which took place in the fall of 1965 in the convent Abbaye des Prémontrés by the Mosel river, near Pont-à-Mousson. This meeting was attended by friends and researchers from France, Belgium, Germany, Italy and Switzerland. Thirty young men presented altogether 60 papers on the topics: Use of THAM to correct surgical acidosis, experimental burns, surgical pathophysiology and organ transplantation.

The meeting led to the foundation of the 'European Society of Experimental Surgery' (it started with three languages and three names: Société Européenne de Chirurgie Experimentale, Europäische Gesellschaft für Experimentelle Chirurgie and European Society of Experimental Surgery) and the election of the first officers in 1966: R. Bénichoux, president; J.J. Haxhe (Louvain) 1st vice president; W. Brendel (Munich) 2nd vice president; U.F. Gruber (Davos), treasurer, and Ch. Marchal (Nancy) secretary general.

Under the presidency of U.F. Gruber (Basel), in 1969 the society adopted the lingua franca English as the offi- cial language and changed its name 1974 into the European Society for Surgical Research (ESSR).

Roger Bénichoux watched his society closely and vigorously: he never left the annual congress and the general assembly without having made major inputs on the scientific program and society policy.

He edited the first publication of the young society called 'Le bulletin jaune', printed in Nancy. He also started the first journal 'Chirurgie expérimentale', which in 1969 was succeeded by European Surgical Research (Karger Publishers, Basel), which this year became, once more, the official journal of the European Society for Surgical Research. Needless to say, Roger Bénichoux was among the founders of European Surgical Research and until his retirement he was a member of the Editorial Board of this thriving journal, the first true European surgical periodical.

Personally, I had the privilege of accompanying Professor Bénichoux as a founding member of the ESSR, as a member of the editorial board of ESR and later as its Editor-in-Chief and, most importantly, as a friend with a firm belief in our national roots as a basis for a united Europe.

The contributions of Roger Bénichoux in this respect are numerous and invaluable. In 2003 the European Society for Surgical Research is still more indebted to him than anybody else in terms of international spirit and pacemakership. Unfortunately, only a few of todays' active members of the ESSR have known the founder of the society personally - nevertheless, what they should learn from the late founder of ESSR is that vision, personal courage and enthusiasm will always allow one to reach new horizons.

The journal European Surgical Research and the ESSR have experienced a great loss - what remains for us to say is - thank you Professor Bénichoux.

Konrad Messmer, Editor-in-Chief 